\title{
Preliminary Evaluation of Composite Panels Produced from Rice Husk and Recycled Polystyrene Material
}

\author{
Ayodele Akinterinwa*, Jamila Umar Atiku, Jude Edogbo Eneche, Kefas Wathagrda Shalbugau \\ Department of Chemistry, Modibbo Adama University of Technology, Yola, Nigeria \\ * Corresponding author email: ayoterinwa@yahoo.com
}

Received: 04 September 2020 / Accepted: 29 October 2020 / Published: 22 November 2020

\begin{abstract}
Rice husk particles categorised as fine (size $\leq 0.6 \mathrm{~mm}$ ), and coarse $(0.6 \mathrm{~mm} \leq$ size $\leq 1.8 \mathrm{~mm}$ ) were mixed with a binder obtained by recycling expanded polystyrene waste, to formulate composites. Formulation was carried out using different particles to binder ratios as follows: 1:1, 1:1.5, 1:2). Fine particle composites were designated F1:1, F1:1.5 and F1:2, while the coarse particle composites were designated C1:1, C1:1.5 and C1:2. The composites were casted, and some physical properties such as: dry/cure time in air $(72 \pm 4 \mathrm{~h}$ - $168 \pm 6 \mathrm{~h})$, density $\left(0.48 \pm 0.04 \mathrm{~g} / \mathrm{dm}^{3}-2.75 \pm 0.08 \mathrm{~g} / \mathrm{dm}^{3}\right)$, water absorption $(2.24 \pm 0.46 \%-58.91 \pm 1.11$ $\%)$ and thickness swelling $(1.43 \pm 0.06 \%-22.65 \pm 1.23 \%)$, flammability tests and SEM images of the composite panels obtained were evaluated. Results showed that: dry time and density increased, water absorption and thickness swelling decreased while flammability increased (ignition time decreased and propagation rate increased), as the amount of the recycled polystyrene binder was increased in the composites. Relative to particle size aggregate, coarse particle composites exhibits shorter drying time, lower density, higher water absorption and weaker flame retardation compared to the fine composites with corresponding ratios.
\end{abstract}

Keywords: Composite panels, expanded polystyrene (EPS), recycled polystyrene (RPS), rice husk (RH), wastes.

\section{Introduction}

Solid wastes constitute a global challenge, and this is more severe in developing countries because of the rapidly increasing population growth, urbanization, industrialization and economic development [1]. Consequently, solid waste management will continue to be in the forefront of research and development.

Rice husk $(\mathrm{RH})$ is the tough protective coat on the rice gain which constitute abundant by-product from rice processing. It has been reported that about 0.23 tons of the $\mathrm{RH}$ are generated per ton of rice milled [2]. Hundreds of millions of tonnes of rice are globally processed every year, and about one fifth of these are $\mathrm{RH}$ obtained as waste. $\mathrm{RH}$ contains protein, lignin, cellulose, fat, silica $\left(\mathrm{SiO}_{2}\right)$ and other minor nutrients, while its major elemental composition includes: carbon, oxygen and silicon [3]. RH has been channeled to many profitable applications. It has found extensive use in the production of composite materials with varieties of adhesives/binders based on its low bulk density (90-150 kg/m³), toughness, abrasion and resistance to weathering [4-5]. It has been transformed to organic fertilizer [6]. It has been used as substitute for fossil fuel in the generation of electricity, and in the production of other form of energy such as cellulosic ethanol [7]. RH power plants generate RH ash. The main component (83$90 \%$ ) of the ash is amorphous silica, and current researches have used it in the production of silica gels, silicon chip, silica fertilizer, activated carbon and silica, supplementary cementitious material, 
light weight construction and insulation materials, catalysts, zeolites, ingredients for lithium ion batteries, graphene, energy storage/capacitor, carbon capture, and in drug delivery vehicles [8-11]. Despite all these applications a large quantity of $\mathrm{RH}$ generated still ended up as waste, thereby constituting environmental problems. This situation is therefore emphasizing the need to constitute more sustainable applications of $\mathrm{RH}$.

Expanded polystyrene (EPS) is a closed cells structure containing $1.5-2 \%$ polystyrene and 98 $98.5 \%$ air. It is produced by expansion of polystyrene using hydrocarbon propellant or blowing agents such as; pentane, isopentane and butane [12-13]. They are voluminous materials largely used in packaging because of its low cost, excellent impact strength, acoustic isolation, light weight, easy processing, versatility, dimensional stability and clean nature [14-15]. After use, these materials constitute another category of solid waste which are typically dumped in landfills or burnt (without complying with environmental safety regulations), thereby creating environmental problems [1, 15-16]. EPS has been recycled based on technical, environmental and economic considerations, and reused in different in various ways such as in: wood plastic composite, concrete for the external facing of buildings with thermal insulation properties and to reduce the porosity and permeability of cement, fiber parts for filtration systems, the processing of virgin EPS, biodiesel production and the re-generation monomer by catalysis [1, 15, 17-18]. Despite these, EPS still constitute a large solid waste, and recent researches are still being focused on novel recycling and reuse techniques [19].

Composite panels or particleboards production is conservative, and they are increasingly substituted for wood in building, furniture and fitments. The rising preference for the use of particleboards can be related to the economic advantage of the low cost of wood raw material, inexpensive agents and simple processing [20]. About $95 \%$ of the lignocellulosic material used for particleboard production is wood. However, recent environmental concerns have widened the interest in manufacturing sustainable materials based on renewable resources other than wood: such as agricultural wastes including RH [20-21].

In this study, EPS was dissolved to constitute the recycled polystyrene (RPS) used as the binder with $\mathrm{RH}$ particles of different size aggregation, in the formulation of composite material casted to dry and form a structural panel. Some physical properties and the flammability of the composite panel formed were also evaluated to preliminarily establish the potentials of the material.

\section{Materials and Method}

\subsection{Materials}

RH was obtained from local rice mill in Jimeta, Nigeria. EPS materials were collected from electronics packaging and petrol was purchased from local filling station in Jimeta, Nigeria. Sieves $(1.8 \mathrm{~mm}$ and $0.6 \mathrm{~mm})$ were obtained from Civil engineering workshop in the University, and the moulds were also fabricated from the workshop.

\subsection{Formulation of RH/RPS composite panels}

RH (Figure 1a) was sorted to carefully remove dirt and other extraneous materials before it was dried in the oven at $100{ }^{\circ} \mathrm{C}$ for $3 \mathrm{~h}$. Thereafter, it was pounded and first sieved through the $0.6 \mathrm{~mm}$ sieve. Sieving was stopped when the particles no more going through the sieve appreciably, the fine particles collected was kept in a polyethylene bag. $\mathrm{RH}$ was then transferred to the $1.8 \mathrm{~mm}$ sieve to collect the coarse particles which were kept in another polyethylene bag.

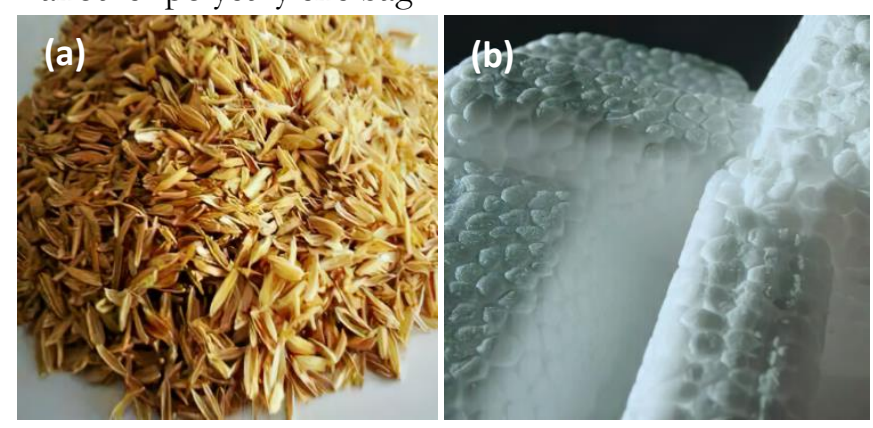

Figure 1. (a) Rice husk and (b) expanded polystyrene 
RPS binder was prepared by modifying the method reported by Osemeahon et al., [22] as follows: $50 \mathrm{~g}$ of EPS materials (Figure 1b) was immersed and starred to completely dissolve in $150 \mathrm{~mL}$ of petrol. Formulation of both fine and coarse RH particle composite was carried out as follows: a clean 150 $\mathrm{ml}$ beaker was placed on a weighing balance and the instrument was zeroed. RPS was poured into the beaker and the weight was recorded. RH particles was also weighed to give specific RH:RPS ratio 1:1, before it was added to the RPS and mixed thoroughly using a metal rod till a homogenous mixture was attained (about $10 \mathrm{~min}$ ). The procedure was repeated taking different weights of RPS to obtain composite with RH: RPS ratio 1:1.5 and 1:2 (Table 1). A laboratory scale casting was carried out by pouring the mixture into an aluminum mould with dimension $7 \mathrm{~cm} \times 2 \mathrm{~cm} \times$ $2 \mathrm{~cm}$, leveled and left to air dry to a structural panel.

Table 1. RH/RPS composite formula

\begin{tabular}{|l|l|l|}
\hline Ratio & RH $(\mathrm{g})$ & RPS $(\mathrm{g})$ \\
\hline $1: 1$ & 50 & 50 \\
\hline $1: 1.5$ & 50 & 75 \\
\hline $1: 2$ & 50 & 100 \\
\hline
\end{tabular}

\subsection{Determination of physical properties of formulated composite panels}

Drying was monitored by sticking a needle into the composite to test hardness, and checking the weight loss till constant weight was obtained. Density was determined by immersing a preweighed $(10 \mathrm{~g})$ cleaned sample of composite panel completely into a $1000 \mathrm{~cm}^{3}$ capacity measuring cylinder partially filled with distilled water, and measuring the volume of water displaced, and Equation 1 was used in calculating density [23].

Density $\left(\frac{\mathrm{g}}{\mathrm{cm}}^{3}\right)=\frac{\text { Weight of composite material }}{\text { Volume of } \text { water displaced }}$

Water absorption determination was carried out by immersing a dried and weighed piece of composite panel $\left(\mathrm{W}_{0}\right)$ in distilled water at $25^{\circ} \mathrm{C}$ for a period of time: 2, 12, 24 and $48 \mathrm{~h}$. After the designated time, the panel was removed and the surface droplet was wiped with a clean dry cotton cloth before it was weighed again $\left(\mathrm{W}_{\mathrm{t}}\right)$. Percentage water absorption was calculated according to Equation 2. [24].

Water uptake $(\%)=\frac{W_{t}-W_{0}}{W_{0}} \times 100$

To determine the thickness swelling of the panel, a $2 \mathrm{~cm} \times 2 \mathrm{~cm} \times 2 \mathrm{~cm}$ dimension piece $\left(\mathrm{H}_{0}=2 \mathrm{~cm}\right)$ was carefully cut out of a dried panel and soaked in distilled water at $25^{\circ} \mathrm{C}$ for a period of time: 2, 12, 24 and $48 \mathrm{~h}$. After the designated time, the panel was removed and the height was measured again $\left(\mathrm{H}_{\mathrm{t}}\right)$. Percentage swelling was calculated according to Equation 3 [23].

Thickness swelling $(\%)=\frac{H_{t}-H_{0}}{H_{0}} \times 100$

\subsection{Flammability tests}

A propagation distance (PD) mark was made at 5 $\mathrm{cm}$ measured on a well casted panel, this was projected downwards, and the upper part of the panel was clamped horizontally onto the clip of a retort stand. The panel was ignited with the aid of a steady burning fire lighter from beneath. Time taken for the sample to ignite was recorded as the ignition time. Propagation rate was calculated from the propagation distance and propagation time (PT) taken to burn to the mark according to Equation 4. [25].

Propagation rate $(\mathrm{mm} / \mathrm{s})=\frac{P D}{P T}$

The weight of the panel $\left(\mathrm{W}_{\mathrm{p}}\right)$ and the weight of char $\left(W_{c}\right)$ collected after the flame had completely burnt out by itself, were used in calculating percentage char formation according to Equation 5.

Char formation $(\%)=\frac{W_{c}}{W_{p}} \times 100$

\subsection{Scanning electron microscopy (SEM) analysis}

SEM analysis was carried using Thermo Scientific Phenom ProX G6 desktop scanning electron microscope (SEM) at the Materials Analysis and 
Research Laboratory of the Department of Chemical Engineering, Ahmadu Bello University, Zaria, Nigeria.

\subsection{Statistical analysis}

All experiments were carried out in triplicates. Statistical Package for the Social Science (SPSS, Version 12.0, 2004, SPSS Inc., Chicago, IL, USA), was used in analyzing data, where it was subjected to one-way analysis of variance (ANOVA) and Duncan's multiple comparison.

\section{Result and Discussion}

The pictorial presentation of pieces of the formulated composite panel is presented in Figure 2. It was observed that the fine composite panels have smoother surfaces, while the increase in the amount of RPS used in the formulations increased the surface sheen of both fine and coarse composite panels.
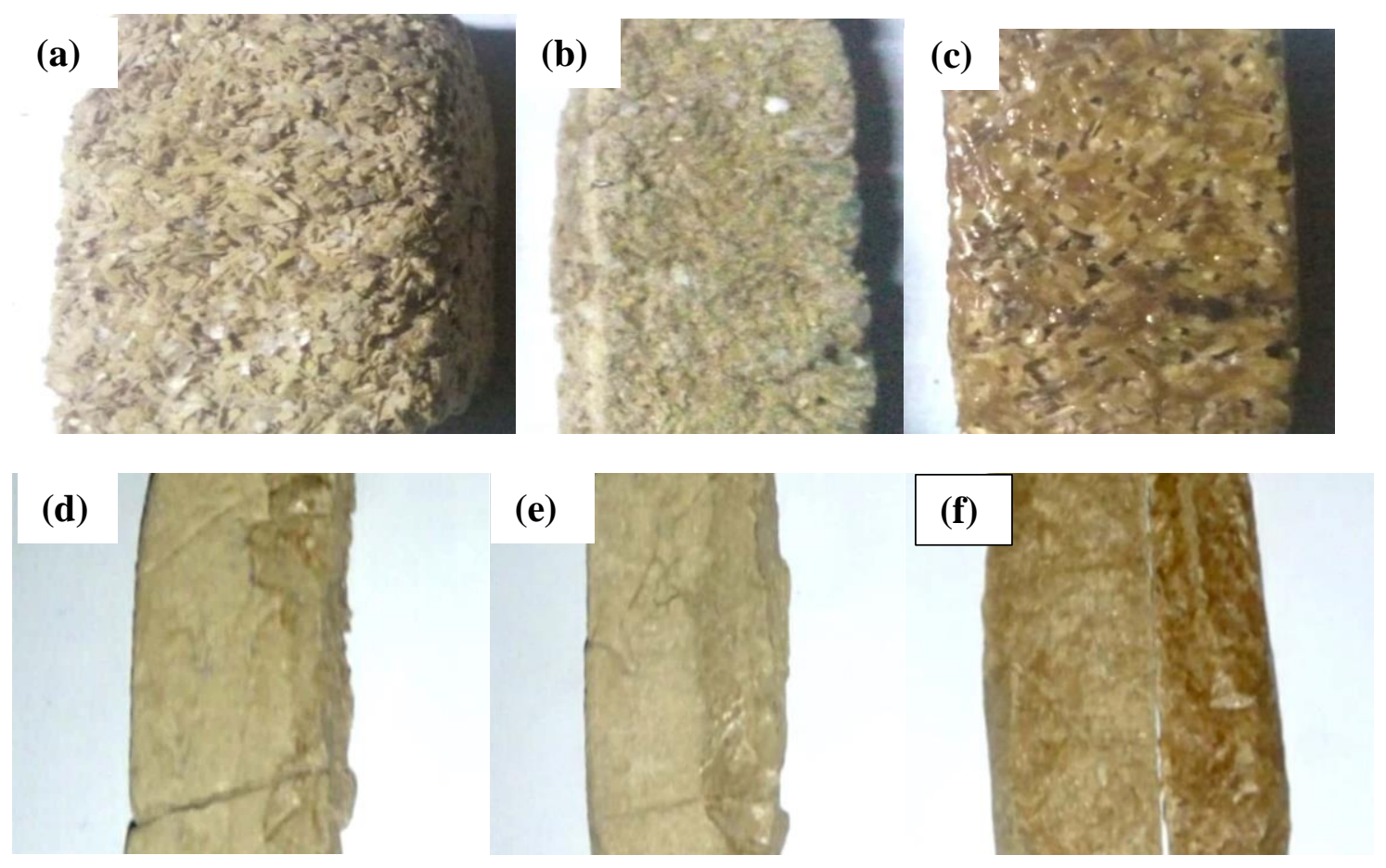

Figure 2. Pictorial presentation of a piece of RH/RPS composite panels (a) C1:1 (b) C1:1.5 (c) C1:2 (d) F1:1 (e) F1:1.5 (f) F1:2

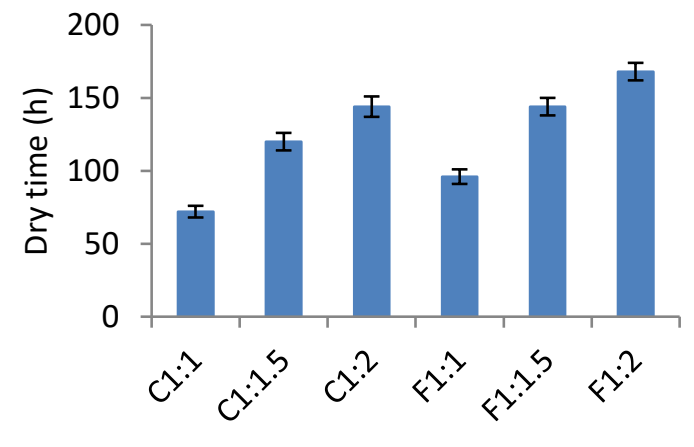

RH/RPS composite panels

Figure 3. Dry time of RH/RPS composite panels

\subsection{Dry time}

The drying time of the composite panels is presented in Figure 3. Composite panel formulated with coarse RH and the least amount of RPS (C1:1) took $72 \pm 4 \mathrm{~h}$ to completely dry, and this was the fastest among others. F1:2 was the slowest drying composite panel $(168 \pm 6 \mathrm{~h})$. Drying time under atmospheric condition can be deduced to be directly proportional to the amount of RPS in the formulation. RPS dries via evaporation of the solvent (petrol) used. Since the rate of evaporation 
of the solvent is reduced in more compact particles (such as in fine particles boards), the fine composite panel may exhibit correspondingly longer drying time compared to the coarse composite panels. There was a general decrease in the weight of the panels obtained compared to the composite casted [26]. Air drying was carried out in the laboratory within temperature range $20{ }^{\circ} \mathrm{C}$ to $31{ }^{\circ} \mathrm{C}$ (at night and day respectively). Faster drying time may be achieved outdoors under direct sun [4, 27]. However, oven drying is not recommended to avoid ignition of hydrocarbon vapour.

\subsection{Density}

The density of the composite panels formulated is presented in Figure 4.

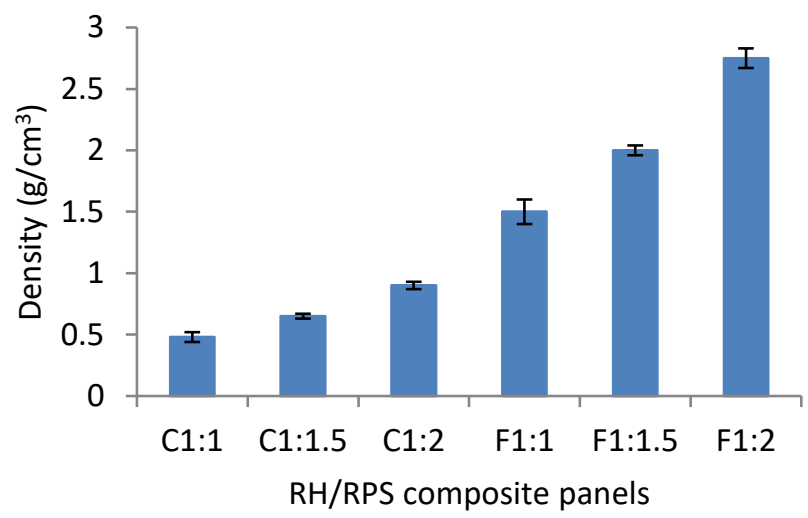

Figure 4. Density of RH/RPS composite panels

The highest value was recorded for F1:2 (2.75 \pm 0.08 $\left.\mathrm{g} / \mathrm{cm}^{3}\right)$, while the lowest was recorded for $\mathrm{C} 1: 1$ $\left(0.48 \pm 0.04 \mathrm{~g} / \mathrm{cm}^{3}\right)$. Increase in the amount of binder in composite panels increased density as similarly reported by Ciannamea et al., [21] and Ajikashile et al., [28]. However, density is more dependent on the particle sizes. Composites with fine particles of $\mathrm{RH}$ exhibits higher densities compared to coarse particle composite with corresponding formulation ratios. This is due to compact packing of more fine particles, hence aggregating to a larger mass within a specific volume compared to the coarse particle. The densities of the coarse particle composite panels fall within the Indonesia National standard range 0.5 $0.9 \mathrm{~g} / \mathrm{cm}^{3}$ [29]. Density has significance influence on the mechanical properties of particleboards: therefore, high density obtained for the fine particle composite panels may indicate strength and durability [30].

\subsection{Water absorption}

Water absorption can be advantageous in some materials e.g. hydrogels [31]; however, it is defective in other materials such as particle/composite panels [32]. Figure 5 shows the water absorption of the RH/RPS composite panel. Increase in RPS amount in the composite panels generally lowers water absorption. This is due to increase in hydrophobicity impacted by RPS, and the reduction in water affinity impacted by RH [33]. Coarse composite panels samples exhibited higher overall rate and equilibrium water absorption compared to their ratio correspondent fine composite panels i.e. C1:1>F1:1; C1:1.5>F1:1.5; $\mathrm{C} 1: 2>\mathrm{F} 1: 2$. This can be attributed to the availability of more void spaces in the coarse particle composites due to less compact aggregation compared to the fine particles [34]. C1:1 in exception exhibited lower equilibrium water absorption (47.15\% after 12 hours), compared to F1:1 (58.91\% after 24 hours), and this could be attributed to water access to a higher mass of a compact aggregate of hydrophilic RH particles with large surface area. The range for water absorption obtained in this study $(2.24 \pm 0.46 \% \quad-$ $58.91 \pm 1.11 \%$ ), are of merits compared to the $20 \%$ - $75 \%$ range by FAO [35].

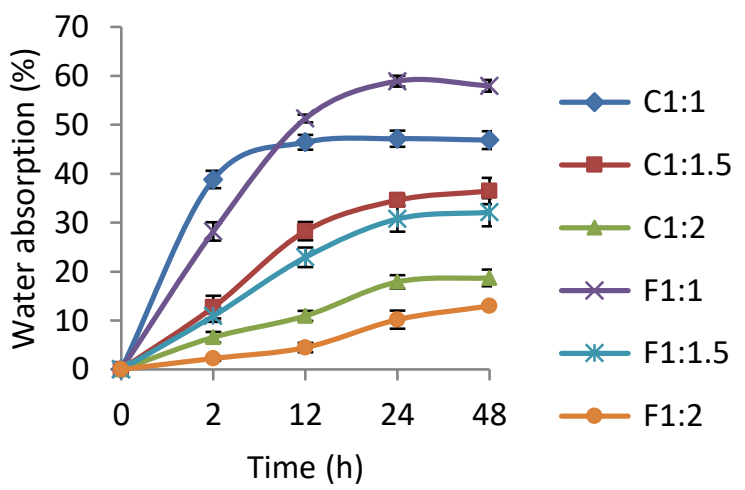

Figure 5. Water absorption of RH/RPS composite panels 


\subsection{Thickness swelling}

Swelling was measured as an effect of water absorbed into the mass of the composite panels. When water or other compactible liquids are absorbed by components of a material, increase in their sizes may occur, which may result in aggregate increase in size of the material. Liquid trapped in void spaces in materials are usually insignificant to swelling. As shown in Figure 6, fine particle composite panel with the least amount of RPS (F1:1) exhibits the highest and most rapid swelling. This can be attributed to two factors; (1) lower amount of RPS, which allows more water access to RH particles; (2) the large surface area of the fine particle, which allows high rate of water absorption and maximum swelling. The least swelling was recorded for samples with the highest amount of RPS [28]. Higher amounts of RPS in these materials result in the restricted water access to the hydrophilic RH particles, especially in the cores of the composite panels. At $2 \mathrm{~h}$ of immersion, all composite panel sample satisfied $<12 \%$ standard [29]. At $12 \mathrm{~h}$ of immersion, all composite panels except F1:1 satisfied the standard, while at $24 \mathrm{~h}$ and beyond, only F1:2 and C1:2 satisfied the standard.

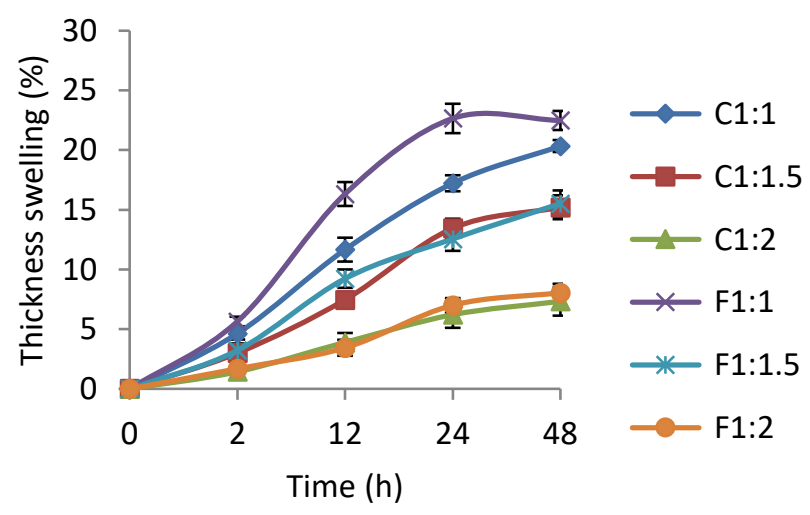

Figure 6. Thickness swelling of RH/RPS composite panels

\subsection{Flammability Test}

Some flame properties of the formulated composite panels were presented. Figure 7 presents the ignition time of the composite panels. Ignition time decreased as the amount of RPS was increased in both coarse and fine particle composite panels. Since RH has been classified as 'not easily ignitable" [36], RPS is the component increasing the ease of composite panel ignition. Comparing fine and coarse particle composite panels with corresponding formulation ratios, ignition is slightly slower with the fine particle composite panels. This can be attributed to the fine particle compactness which slightly impact flame retardation. Figure 8 presents the rate of flame propagation on the composite panels. Flame propagation also increased with the amount of RPS in the formulations: however, coarse particle composites consistently exhibit higher rates than the fine particle composites with corresponding ratios. This can be attributed to higher amount of void spaces (due to loose packing of larger particles), trapping air that enhance the propagation of the flame. Figure 9 present the amount of char formed as a percentage mass of the composites. There were no significant differences in char formation due to particle sizes, because same amount of char was formed from same mass of RH incorporated into the composite panels regardless of the sizes. Also, there was no significant difference in char formation due to the amount of RPS incorporated into the composite panels because: significant mass of the RPS vaporised on flame, leaving an insignificant mass in the remnant char.

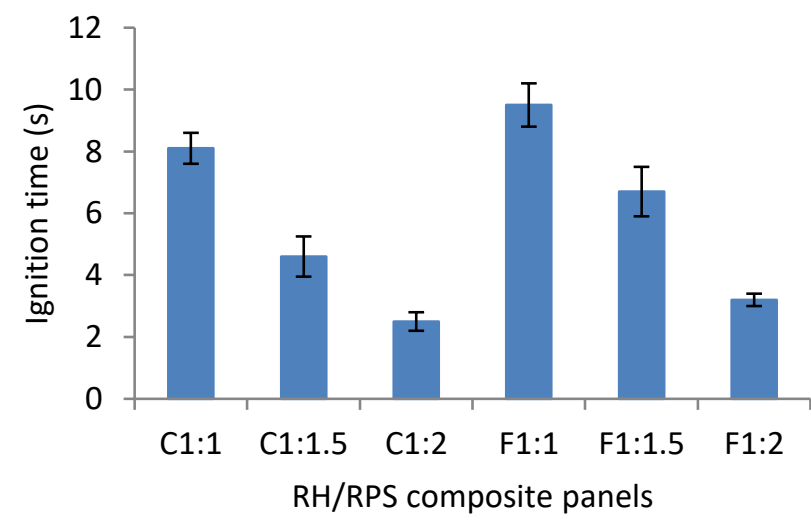

Figure 7. Flame ignition time of RH/RPS composite panels 


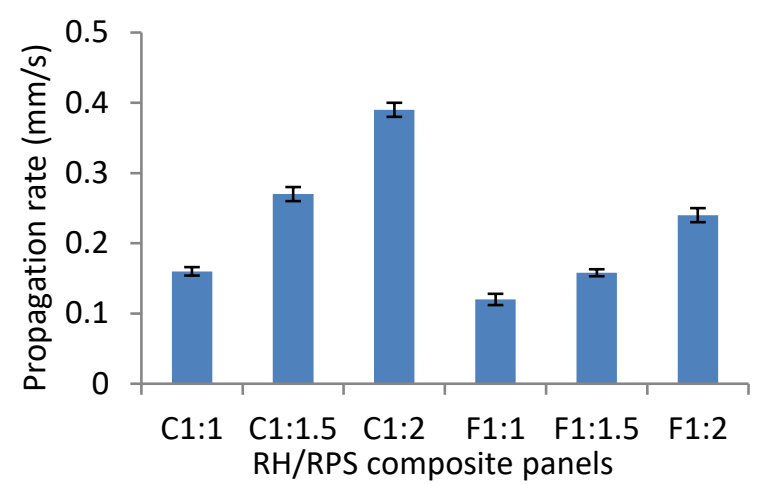

Figure 8. Flame propagation rate of RH/RPS composite panels

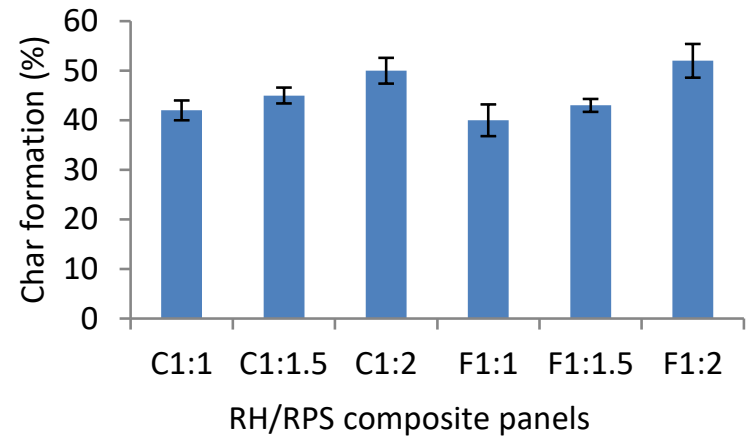

Figure 9. Char formation from RH/RPS

composite panels

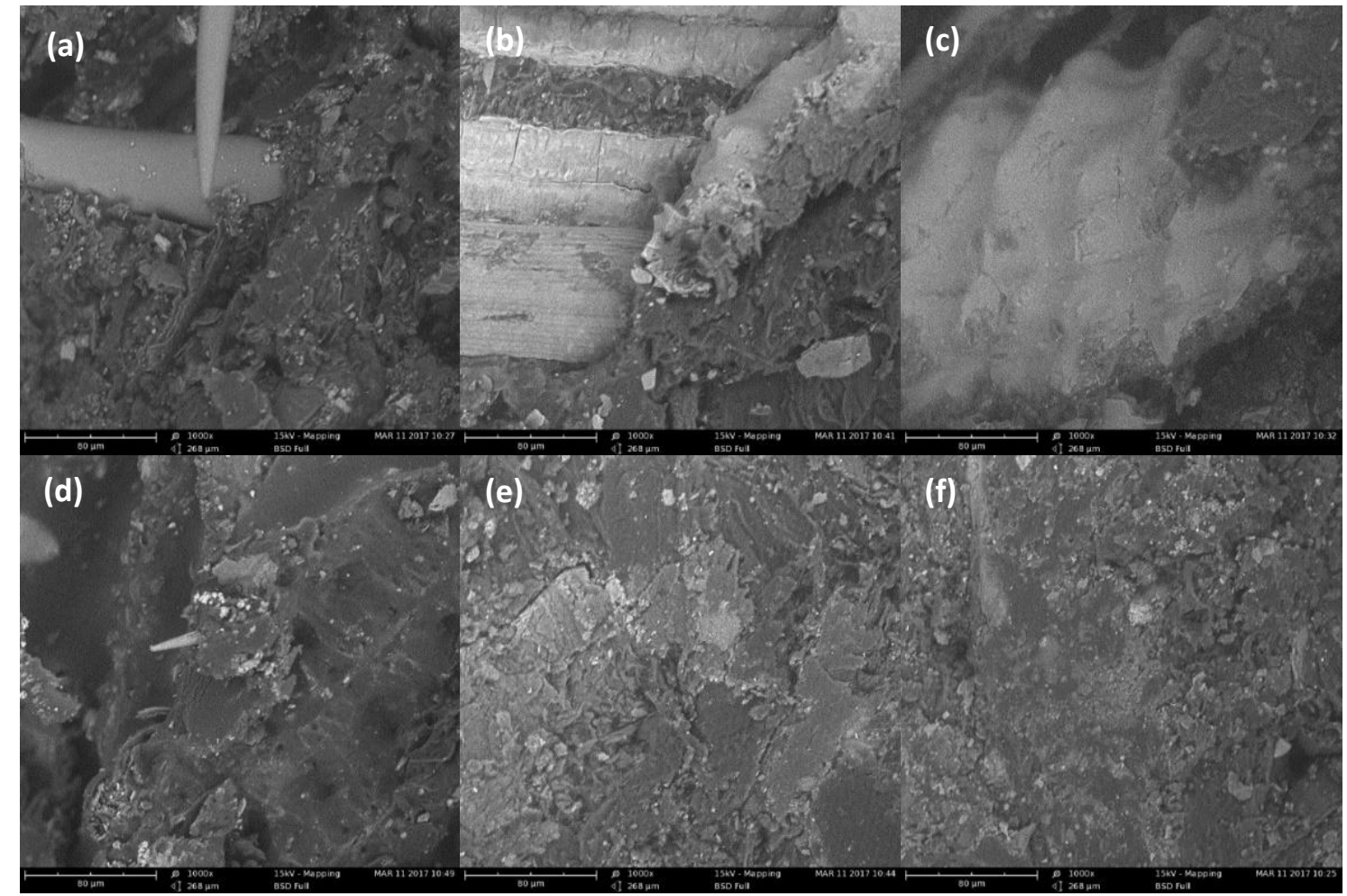

Figure 10. SEM images of RH/RPS composite panels (a) C1:1, (b) C1:1.5, (c) C1:2, (d) F1:1, (e) F1:1.5 (f) F1:2

\subsection{SEM}

SEM images of the surfaces of the composite panels are presented in Figure 10. The whitish portions indicates RPS rich segments, dark grey portions indicates segments with homogeneous $\mathrm{RH} / \mathrm{RPS}$ mixture, while the black spots indicates void spaces on the surfaces of the composites. Figure 11a (C1:1), 11b (C1:1.5) and 11c (C1:2) showed that the coarse $\mathrm{RH}$ particles are not uniformly distributed in the composite. As the amount of RPS was increased, the RPS rich segment was more established, thereby showing two distinct segments on the composite panels formed. The coarse particle composite panel also exhibits larger void spaces. Figure 11d (F1:1), 11e (F1:1.5) and 11f (F1:2) showed better distribution of the fine particles in the composite panels. The distribution of the particles also improves as the amount of RPS was increased: thereby, showing more homogenous surface. Void spaces on these composites are smaller and fewer. (c) 


\section{Conclusion}

Composite panels were produced from $\mathrm{RH}$ particles and EPS which are both considered as wastes. In the simple and low cost procedure used, different amounts of the binder (RPS) and two RH particle size aggregates categorized as fine (particle size $\leq 0.6 \mathrm{~mm})$, and coarse $(0.6 \mathrm{~mm} \leq$ particle size $\leq 1.8 \mathrm{~mm}$ ) were involved in the formulation of the composites. Results obtained showed that the amounts of RPS binder in the composite as well as the different particle size aggregations influenced the properties of the composite panels produced. Some results obtained can be favorably compared with standard values, and this indicated the good potentials of the composite panel produced.

\section{Declarations}

\subsection{Study Limitations}

The study is limited to some basic physical properties of the composite panel. Further studies will dive deeper into the mechanical studies.

\subsection{Acknowledgements}

Authors acknowledge the undergraduate students: Ismail Abdulahi, Victoria Peters, Samuel Haruna and Precious Muzong, who participated in the field and bench works. Authors also acknowledge the entire technical staff of both Chemistry Laboratory and Civil Engineering workshop of Modibbo Adama University of Technology, Yola, Nigeria, and Materials Analysis and Research Laboratory of the Department of Chemical Engineering, Ahmadu Bello University, Zaria, Nigeria.

\subsection{Competing Interests}

Authors declare no conflict of interest.

\section{How to Cite this Article:}

A. Akinterinwa, J. Umar Atiku, J. E. Eneche, and K. W. Shalbugau, "Preliminary Evaluation of Composite Panels Produced from Rice Husk and Recycled Polystyrene Material", J. Mod. Mater., vol. 7, no. 1, pp. 45-53, Nov. 2020. https://doi.org/10.21467/jmm.7.1.45-53

\section{References}

[1] M. Poletto, J. Dettenborn, M. Zeni, A. J. Zattera, "Characterization of composites based on expanded polystyrene wastes and wood flour", Waste Management, vol. 31, no. 4, pp. 779-784, 2011.

[2] S. Kalia, B.S. Kaith, I. Kaur, "Cellulose fibers: bio- and nano-polymer composites: green chemistry and technology", Dordrecht: Springer Heidelberg, 2011.

[3] R. Jauberthie, F. Rendell, S. Tamba, I. Cisse, "Origin of the pozzolanic effect of rice husks", Construction and Building Materials, vol. 14, no. 8, pp. 419-423, 2000.

[4] A. C. Johnson, Y. B. D. E. D. Nordin, "Particleboards from rice husk: a brief introduction to renewable materials of construction", Cellulose, vol. 28, pp. 38, 2009.

[5] A. K. Temitope, A. T. Onaopemipo, A. A. Olawale, O. O. Abayomi, "Recycling of rice husk into a locally-made water-resistant particle board", Ind Eng Manage, vol. 4, no. 164, pp. 2169-0316, 2015.

[6] S. L. Lim, T. Y. Wu, E. Y. S. Sim, P. N. Lim, C. Clarke, "Biotransformation of rice husk into organic fertilizer through vermicomposting", Ecological Engineering, vol. 41, pp. 60-64, 2012.

[7] J. Prasara-A, T. Grant, "Comparative life cycle assessment of uses of rice husk for energy purposes", The International Journal of Life Cycle Assessment, vol. 16, no. 6, pp. 493502, 2011

[8] M. F. M. Zain, M. N. Islam, F. Mahmud, M. Jamil, "Production of rice husk ash for use in concrete as a supplementary cementitious material", Construction and building materials, vol. 25, no. 2, pp. 798-805, 2011.

[9] R. Pode, "Potential applications of rice husk ash waste from rice husk biomass power plant", Renewable and Sustainable Energy Reviews, vol. 53, pp. 1468-1485, 2016.

[10] M. Tateda, "Production and effectiveness of amorphous silica fertilizer from rice husks using a sustainable local energy system", Journal of Scientific Research and Reports, pp. 1-12, 2016

[11] J. Prasara-A, S. H. Gheewala, "Sustainable utilization of rice husk ash from power plants: A review". Journal of Cleaner Production, vol. 167, pp. 1020-1028, 2017.

[12] J. R. Freid, "Polymer Science and Technology (2nd Edition)" Peason Education Inc., Upper Saddle River, New Jersey, USA, pp. 294-303, 384.

[13] A. M. Papadopoulas, "State of Art in Thermal Insulation Materials and Aims for Future Development", Energy and building, vol. 37, pp. 77-86.

[14] C. Shin, "Filtration application from recycled expanded polystyrene" Journal of Colloid and Interface Science, vol. 302, no. 1, pp. 267-271, 2006.

[15] M. D. Samper, D. Garcia-Sanoguera, F. Parres, J. Lopez, "Recycling of expanded polystyrene from packaging" Progress in Rubber Plastics and Recycling Technology, vol. 26, no. 2, pp. 83-92, 2010.

[16] C. Wu, M. A. Nahil, N. Miskolczi, J. Huang, P. T. Williams, "Processing real-world waste plastics by pyrolysis-reforming for hydrogen and high-value carbon nanotubes", Environmental science and technology, vol. 48, no. 1, pp. 819-826, 2014. 
[17] A. Kan, R. Demirboğa, "A new technique of processing for waste-expanded polystyrene foams as aggregates" Journal of materials processing technology, vol. 209, no. 6, pp. 2994-3000, 2009.

[18] M. A. Rajaeifar, R. Abdi, M. Tabatabaei, "Expanded polystyrene waste application for improving biodiesel environmental performance parameters from life cycle assessment point of view", Renewable and sustainable energy reviews, vol. 74, pp. 278-298, 2017.

[19] N. D. Gil-Jasso, M. A. Segura-González, G. Soriano-Giles, J. Neri-Hipolito, N. López, E. Mas-Hernández, C. E. Barrera-Díaz, V. Varela-Guerrero, M. F. BallesterosRivas, "Dissolution and recovery of waste expanded polystyrene using alternative essential oils", Fuel, vol. 239, pp. 611-616, 2019.

[20] M. Gürü, S. Tekeli, I. Bilici, "Manufacturing of ureaformaldehyde-based composite particleboard from almond shell", Materials and design, vol. 27, no. 10, pp. 11481151, 2006.

[21] E. M. Ciannamea, D. C. Marin, R. A. Ruseckaite, P. M. Stefani, "Particleboard based on rice husk: Effect of binder content and processing conditions", Journal of renewable materials, vol. 5, no. 5, pp. 357-362, 2017.

[22] S. A. Osemeahon, I. I. Nkafamiya, O. N. Maitera, A. Akinterinwa, "Synthesis and Characterization of Emulsion Paint Binder from a Copolymer Composite of Dimethylol Urea/Polystyrene", Journal of Polymer and Composites, vol. 3, no. 2, pp. 11-21, 2015.

[23] BSI (1993). BS EN 321, "Fibreboards - Cyclic Tests in Humid Conditions", The British Standards Institution, London, 1993.

[24] ASTM D570-98, "Standard Test Method for Water Absorption of Plastics", ASTM International, West Conshohocken, PA, 2005, www.astm.org.

[25] P. M. Dass, B. Mathias, A. Andrew, M. A. Atoshi, "Water Absorption, Flammability, Hardness and Morphology Tests on Composite Prepared from High Density Polyethylene Films/Doka Wood Dust Particles", British Journal of Applied Science and Technology, vol. 17, no. 5, pp. 1-10, 2016.

[26] T. Ota, T. Okamoto, "Mechanical properties of particleboard made from rice husk", Journal of Materials Science and Engineering B, vol. 5, no. 8, pp. 263-269, 2015.

[27] Z. Pan, A. Cathcart, D. Wang, "Thermal and Chemical Treatments to Improve Adhesive Property of Rice Bran", Ind. Crops Prod, vol. 22, pp. 233-240, 2005.

[28] J. O. Ajikashile, H. O. Ige, M. G. Ikpe, "Potential of using Rice Husk in Particleboard Production", Proceedings of the 1st International conference on Drylands, pp. $41-46$, 2014.

[29] SNI 03-2105-2006, "Particle Boards" National Standardization Agency of Indonesia, 2006.

[30] R. R. D. Melo, D. M. Stangerlin, R. R. C. Santana, T. D. Pedrosa, "Physical and mechanical properties of particleboard manufactured from wood, bamboo and rice husk", Materials Research, vol. 17, no. 3, pp. 682-686, 2014.

[31] I. I. Nkafamiya, A. Akinterinwa, "Controlled swelling and in vitro release of insulin from konkoli grafted polymethylacrylaminde hydrogel”, International Journal of Pharmaceutical Chemistry, vol. 7, no. 4, pp. 63-69, 2017.

[32] L. Muruganandam, J. Ranjitha, A. Harshavardhan, "A Review Report of Physical and Mechanical Properties of Particle Boards from Organic Waste". Journal of ChemTech Research, vol. 9, no. 1, pp. 64-72, 2016.

[33] E. M. Ciannamea, P. M. Stefani, R. A. Ruseckaite, "Medium-density particleboards from modified rice husks and soybean protein concentrate-based adhesives", Bioresource Technology, vol. 101, no. 2, pp. 818-825, 2010.

[34] J. Khedari, N. Nankongnab, J. Hirunlabh, S. Teekasap, "New low-cost insulation particleboards from mixture of durian peel and coconut coir" Building and environment, vol. 39 , no. 1, pp. 59-65, 2004.

[35] FAO, "Fiberboard and particle Board" Food and Agricultural Organization Genewa, 1997.

[36] S. K. Bhatnagar, "Fire and rice husk particleboard" Fire and materials, vol. 18, no. 1, pp. 51-55, 1994.

\section{Publish your research article in AIJR journals- \\ $\checkmark \quad$ Online Submission and Tracking \\ $\checkmark \quad$ Peer-Reviewed \\ $\checkmark \quad$ Rapid decision \\ $\checkmark \quad$ Immediate Publication after acceptance \\ $\checkmark \quad$ Articles freely available online \\ Retain full copyright of your article. \\ Submit your article at journals.aijr.in}

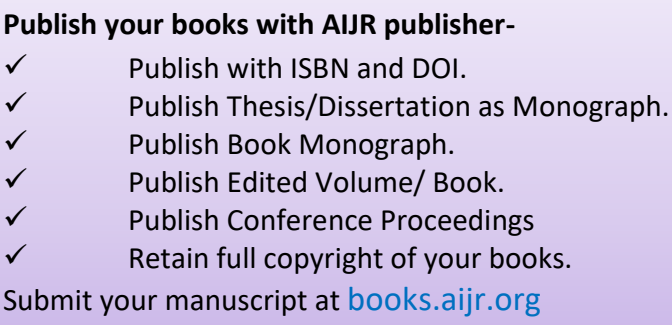

